\title{
Review on Retinal Gliosis Illustrated with a Series of Massive Glioses and Focal Nodular Gliosis Cases in Regard to Potential Pitfalls of Ocular Reactive Tumor-like Lesions of this Type
}

\author{
Andrzej Wincewicz ${ }^{1}$, Sławka Urbaniak-Wasik ${ }^{1}$, Antoinette Urbaniak' , Marlena Mościcka- \\ Rylska ${ }^{1}$, Martyna Woltanowska ${ }^{2}$, Mariusz Koda ${ }^{3}$, Stanislaw Sulkowski ${ }^{3}$, Joanna Reszeć ${ }^{4}$ \\ ${ }^{1}$ Non Public Health Care Unit - Department of Pathology, Kielce, Poland \\ ${ }^{2}$ Non Public Health Care Unit - Primary Health Care (NZOZ POZ) MEDICAMENTO, Wysokie Mazowieckie, Poland \\ ${ }^{3}$ Department of General Pathomorphology, Medical University of Bialystok, Bialystok, Poland \\ ${ }^{4}$ Department of Medical Pathomorphology, Medical University of Bialystok, Bialystok, Poland
}

\section{Correspondence:}

Andrzej Wincewicz, Department of Pathology, Specialist Medical Practice, Jagiellońska 70 Kielce, 25734 Poland

E mail: andwinc@gmail.com

Tel: +48506660426

Received: 01 March 2017

Accepted: 30 May 2017

Published Online: 23 June 2017

Published: 30 March 2018

Key words: retinal gliosis, intraocular tumor, reactive changes, fibrillary astrocytes, Müller cells

Citation: Wincewicz A, UrbaniakWasik S, Urbaniak A, MościckaRylska M, Woltanowska M, Koda M, Sulkowski S, Reszeć J. Review on retinal gliosis illustrated with a series of massive glioses and focal nodular gliosis cases in regard to potential pitfalls of ocular reactive tumor-like lesions of this type. Folia Med (Plovdiv) 2018;60(1):30-8. doi: 10.1515/folmed-2017-0061
This paper presents a review on retinal gliosis illustrated by series of three cases of patients (a 39-year-old man and a 35-year-old woman with massive retinal gliosis (MRG) and a 51-year-old man with truly focal nodular gliosis of retina) with intraocular tumor-like masses and loss of vision, who recently suffered from painful inflammation of eyeball and who classically had a history of remote ocular trauma, onset of blindness early in lifetime or gradual but progressive loss of sight. The diagnosis of this pathological entity is given for the lesions that are composed of GFAP strongly positive, elongated, fusiform cells consistent with fibrillary astrocytes. As illustrated in cases from our pathological practice, PAS gave positive patchy disseminated reaction in form of cellular densely purplish granules in minority of cells representing glycogen storing. This feature could be consistent with PAS-positive Müller cells that also constitute retinal gliosis as one of cellular components of normal retina that is induced to reactive proliferation. Thus, the paper presents histological background and differential diagnosis of the entity.

\section{BACKGROUND}

Retinal gliosis is associated with phthisis bulbi and malformations or congenital disorders. ${ }^{1}$ An eye with phthisis bulbi and massive retinal gliosis can start being painful with indication for surgical removal of blind eye. As there is limited access to handbooks, strictly dedicated to eye pathology, the present review is illustrated with three cases of retinal gliosis for usefulness for unfamiliar readers and encouragement for experts to share - with readership of the journal - less frequent cases of the scope of differential diagnosis of this lesion. In spectrum of reactive responses to eye injury there are closely related lesions with distinctive histological features to justify diversity of nomenclature. ${ }^{2}$ These are namely reactive retinal glioangiosis (RRG), retinal vasoproliferative tumour and massive retinal gliosis (MRG). ${ }^{2}$ The name of each entity emphasize predominant component of their histopathological appearance being to some extent synonymous with each other. ${ }^{2}$

\section{HISTOLOGY OF RETINA ORIENTED ON HISTO- GENESIS OF GLIOSIS}

Classically retinal pigment epithelial (RPE) cells are involved in reactive retinal glioangiosis (RRG), 
which consists of glial cells, abnormal blood vessels, and scattered melanin pigment in a series of six cases of enucleated eyes. ${ }^{2}$ RRG could belong to the spectrum of proliferative vitreoretinopathy, and therefore therapeutic counteraction of proliferative vitreoretinopathy could limit the extend of RRG. ${ }^{2}$ Actually, massive retinal gliosis (MRG) is a type of reactive glial proliferation, which can completely replace the compressed retina that undergoes atrophy and cause deterioration of vision leading to blindness. ${ }^{3} \mathrm{MRG}$ develops in response to trauma of eyeball sometimes after decades of its occurrence. From the phylogenetic point of view, retina of the vertebrates contains the so-called Müller cells that form a sort of unique glial population. In histogenetic aspect which is truly developmental point of view, MRG is associated with a structure called 'preretinal glial membrane', which is emerging via cell proliferation and migration of Müller glial cells, which are also found in humans and therefore are the starting point for reactive, non-malignant growth classified as retinal gliosis. ${ }^{4}$ The main difficulty of diagnosis of MRG lies in unsatisfying knowledge in the field of acquisition of histology of eye. There is a bit confusing surprise that eye ball normally contains some glial cells, which are starting point for that kind of tumor-like proliferation. That way, the misdiagnosis of neoplasm could easily be favored as a de novo growth, if the presence of normal retinal glial cells, so-called Müller cells, is not clearly realized and recalled in diagnostician's mind. It is a banal message, that in order to diagnose neuropathological lesions of retina one must be aware of neural and glial histological components of this anatomical structure. The normal retinal histology is complex and seems to be overshadowed with plentitude of other information of practical diagnostic value in pathologist's mind. However, knowledge of structure of the eye was a challenging task to explore particularly in academic tradition of areas of Regnum Poloniae ever since a lower Silesian physician Vitello published his famous 'Perspectiva' with still appealing to a reader scheme of eye structure in reflection of his meticulous accuracy of mathematician and humbleness of friar as early as in $13^{\text {th }}$ century. ${ }^{5}$ Thus, it might be quite useful and welcomed to present concise overview of retinal cellular types as an introduction to exact histopathological report of three ocular lesions of one pathological entity of glial nature. Namely, among variety of retinal cells there are pigment cells, which absorb light and store vitamin A to provide it to cones (photosensitive receptor cells enabling color vision in brightness) and rods (photosensitive receptor cells launching monochromatic vision in weak light). ${ }^{6}$ Besides them, there are bipolar neurons which contact via synapses with rods and cones to convey signals of light reception to dendrites of ganglion cells. ${ }^{6}$ In addition, there is a kind of modulating cells, which are called horizontal cells, that are regulators of signal transduction at the level of rods and cones and bipolar cells, that are capable to cease the activity of bipolar cells when needed. ${ }^{6}$ Amacrine cells are next cell type that possess properties of interneuron, which decide on transduction of optic signaling to visual cerebral centers. ${ }^{6}$ In the human retina, there are not only Müller cells but also astroglia and microglia, which were all discovered there by Santiago Ramón y Cajal in $1892 .^{7}$ Müller cells are regarded as the main type of retinal glial cells, which within retinal neurons orginate from a single progenitor cell. ${ }^{8}$ Actually, at first stage, primary neurons that include cone cells, horizontal cells and ganglion cells are developed and secondly Müller cells and rod photoreceptors, bipolar cells and amacrine cells are generated from apical neuroepithelium adhering to pigment epithelium. ${ }^{9}$ Müller cells are principal retinal microglia and are specialized radial glia that project their longitudinal processes to communicate retinal neurons. ${ }^{10}$ Müller cells are PAS-positive because they store glycogen, which they provide to retinal neurons. ${ }^{1,10}$ Müller cells contain intermediate filaments, so they are both positive for vimentin and partially for glial fibrillary acidic protein (GFAP). ${ }^{11}$ Besides all supporting properties of glia, Müller cells are a special type of retinal glial cells, which are also characterized by capability of streaming of various wavelength of light to the correct photoreceptor cells via fiber optic cables. ${ }^{6}$ In retina, there are also ganglion cells that serve as cellular intermediaries (or intermediate stations) of signaling on optic tract. Among ganglion cells there is a minor cell population of additional unique properties, which make them contributors to control of pupillary reflex and transmitters of daylight and night information in a way that makes them a sort of residual functional homologues of histological structures, which are indispensable to maintain the body's circadian rhythm and are engaged in signaling of the third eye of less evolutionarily advanced vertebrates. ${ }^{6}$ In opposition to astrocytes and Müller cells, retinal microglial cells are of mesodermal origin and function as residual macrophages, but they are traditionally classified as 
the third glial cell type that populate every layer of the retina. ${ }^{12,13}$ Astrocytes do not belong to the retinal neuroepithelium, but they populate retina via passage along optic nerve during embryonal development. ${ }^{14,15}$ They are flattened and elongated and equipped in numerous fibrous processes, which are densely packed with intermediate filaments to give intense reaction for GFAP. ${ }^{15}$ Presence of astrocytes is actually limited to the nerve fiber layer of the normal retina. ${ }^{15}$

\section{CLINICAL AND PATHOLOGICAL PRESENTATION}

Massive retinal gliosis is usually diagnosed in non functioning eye with association with phthisis bulbi, which is defined as the end-stage ocular degeneration in reaction to severe trauma of the eye. ${ }^{16}$ Phthisis bulbi presents as a shrunken eyeball, a disorganization and atrophia of eye structures. Phthisis bulbi could be induced not only by ocular mechanical injury but also radiation, infective agents, diffuse illness or could arise in association with neoplastic tumors such a retinoblastoma. ${ }^{17}$ Massive retinal gliosis is defined as nonneoplastic retinal glial lesion. ${ }^{5}$ However, not all cases of retinal gliosis are massive so the better name would be reactive retinal gliosis instead of massive retinal gliosis. ${ }^{1}$ Actually, Jakobiec et al. even distinguished three subgroups of retinal glioses: submassive gliosis, massive gliosis and focal nodular gliosis - the latter one as in our case of 51-year-old man. ${ }^{1}$

The clinical course of retinal gliosis is quite characteristic. Namely, it usually occurs at an age of over thirty years. The mean age of occurrence was 36 years, but the age of patients varied from 2 to 79 years in the report of Jakobiec et al. ${ }^{1}$ All cases we encountered belonged to patients who were over 30 years old (a 39-year-old man, 35-yearold woman and 51-year-old man). Each of them suffered painful inflammation of non functioning eyeball that proceeded surgical removal. In case of our patients in their thirties there was onset of blindness early in lifetime (eye injury at the age of 2 years in case of the man or blindness from birth in case of the woman), while in case of man in his fifties there was protracted gradual loss of vision in his left eye. On macroscopic evaluation on the cross-section the vitreous body contained solid tuberous up to $0.8-\mathrm{cm}$-in-diameter masses of spindled texture in the case of the 39-year-old man (Fig. 1). Such a tumor-like masses contain usually solid fields of partially calcified tissue. The marginal calcification of the tumor-like lesion can develop in local osseous metaplasia at the periphery of changes in the vitreous body of the eye (Fig. 1) like eggshell cover. On microscopic evaluation there was reactive nodular hyperplasia of the eyeball in close neighborhood of residual retinal texture (Fig. 2a). Ganglion cells were easily recognizable in $\mathrm{H} \& \mathrm{E}$ slides of the lesion presenting with typical morphology (Fig. 2b). They were dispersed among glial cells being a representation of population of ganglion cells that are normally present in retina. ${ }^{6}$ This tumor-like growth was composed of reactive glial cells that were mostly consistent with elongated, fusiform, fibrillary astrocytes without cytological features of malignancy (Fig. 2c). The cells were placed in the background of neuropil that is characteristic extracellular matrix for every glial lesions (Fig. 2d). PAS gave positive patchy disseminated reaction in the form of relatively big, cellular, densely and deeply purplish granules that often coalesced into conglomerates (Fig. 3a). In our opinion such a PAS positive pattern of staining in depicted cells which could be consistent with in the first place glycogen storing and therefore PASpositive Müller cells. In contrast to purplish color of glycogen granules, small hyalinized abnormal vascular channels stained pink in evidently positive PAS reaction. Both PAS and alcian blue staining was negative in most fibrous spindle cells. In MRG spindled fibrous astrocytes are Alcian blue-negative due to lack of myxoid matrix. ${ }^{1}$ EMA presented with focal staining particularly marking the contours of vessels (Fig. 3b). GFAP was strongly positive (Fig. 3c), while S100 was moderately positive in fusiform cells (not shown). Vimentin was evidently positive (Fig. 3d). These cells were consistent with fibrous astrocytes, which constituted most of cellular population of the lesion. In addition there was atrophy of the retinal epithelium. A proliferation of small vessels was noted under the epithelium of the cornea as well as small calcifications in corneal epithelium. Ciliary body and cornea was chronically and focally inflamed. There was a turbidity and calcification of the nucleus of the lens which was apparently displaced in our case. Other accompanying changes included chronic non-specific low-grade inflammation of the iris and ciliary body. Careful inspection of accompanying changes often gives a clue or at least suggestion that main lesion composed of glial cells is a responsive non neoplastic process with background of reactive alterations. The case of a 51-year-old man strictly fell into one of retinal gliosis subcategories proposed by Jakobiec 


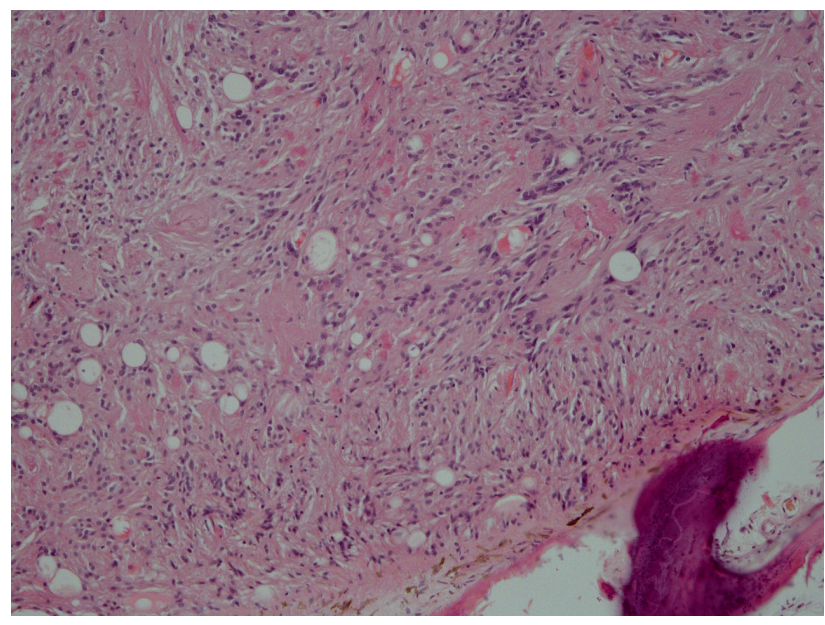

Figure 1. Overview of histological architecture of retinal gliosis with adjacent calcification (H\&E, Magnification 1:100).

et al.: focal nodular gliosis. ${ }^{1}$ Indeed, in this case it was discouraged to call it massive as it was really focal one. It truly presented as a reactive, focal nodular hyperplasia intermingled with histological retinal residues in eyeball. It was composed of reactive, elongated, fusiform glial cells of appearance of fibrillary astrocytes that were placed in neuropil without cytological features of malignancy. This lesion was studded with patchy microfoci of hyalinization (Figs 4a, 4b) and with vessels with delicate rims of hyalinization around them (Figs 4c, 4d). At its periphery this reactive glial growth was accompanied with atrophy of the retinal epithelium, turbidity and calcification the displaced nucleus of lens as well as calcified local bone metaplasia of the vitreous body of the eye, which once again placed glial lesion in appropriate reactive context. GFAP was strongly positive in glial cells. The third case, that of a 35-year-old woman, presented with quite progressed degenerative changes in the form of thick hyalinization of vessels and adjacent areas (Figs 5a, 5b, 5c). Particularly, hyalinized vessels could be reminiscent of hyalinized vessels of ependymoma, but here encountered vessels were not of the kind of typical vessels within pseudorosettes of ependymoma. Under microscopic investigation there was intraocular proliferation of spindle cells or were accompanied with peripheral focal formation of rosette-like structures in close contact to residual retina, scattered small calcifications, focal bone metaplasia and a significantly severe degenerative and microcystic changes. There was strong positivity
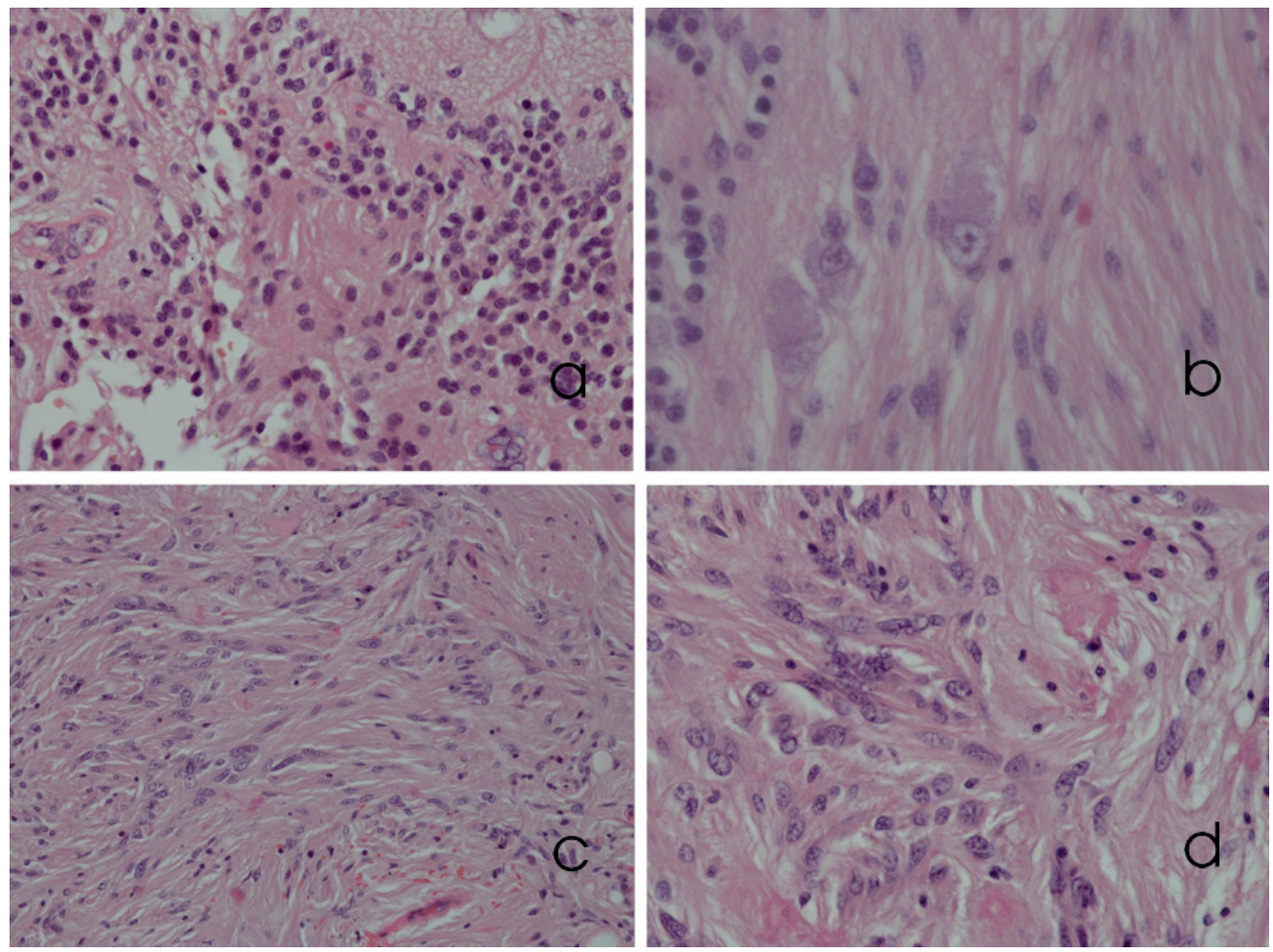

Figure 2. Histopathology of retinal gliosis; Fig. 2a. Residual texture of compressed and translocated, partially defragmented retina at the border of the lesion (H\&E, Magnification 1:400); Fig. 2b. Ganglion cells persisting in the lesion (H\&E, Magnification 1:600); Fig. 2c. Spindle cells arrayed in the solid areas in the haphazard manner (H\&E 1:200); Fig. 2d. Foci of hyalinization within gliosis (H\&E, Magnification 1:400). 

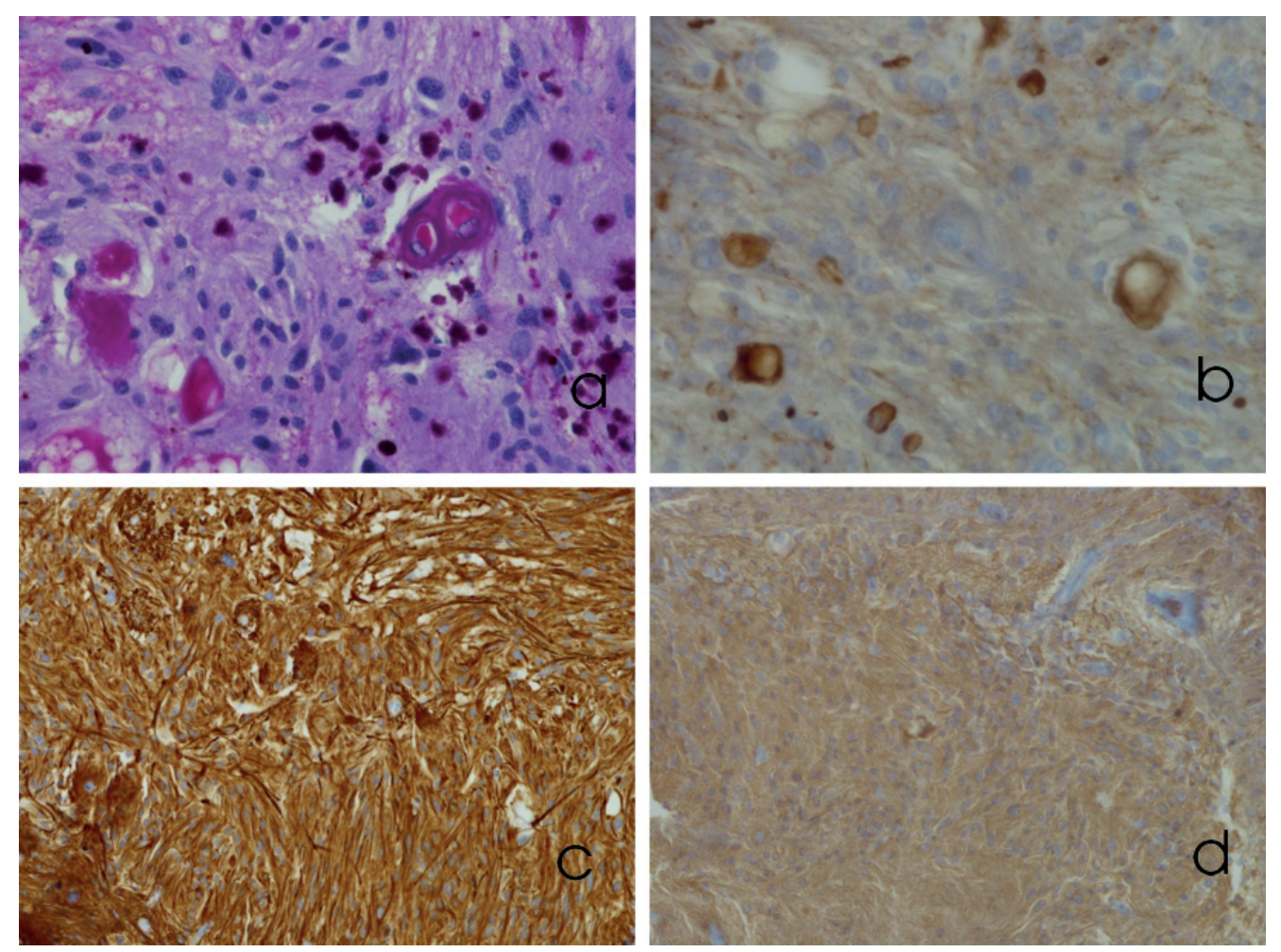

Figure 3. Histochemistry and immunohistochemistry of retinal gliosis. Fig. 3a Disseminated patchy PAS positivity reaction in form of relatively huge cellular densely purplish granules coalesced into conglomerates of glycogen storing and therefore PAS positive Müller cells \& pink colored PAS -positive small hyalinized abnormal vascular channels; negative PAS \& Alcian blue staining in most fibrous spindle cells consistent with fibrous astrocytes, (PAS/Alcian blue, Magnification 1:400). Fig. 3b Focal EMA-staining highlighting the contours of vessels in the lesion (EMA staining, Magnification 1:400). Fig. 3c Arrays of fibrous spindle cells with very strong positivity for GFAP (anti-GFAP staining, Magnification 1:200). Fig. 3d Evidently positive vimentin immunostaining of the lesion (anti-Vimentin staining, Magnification 1:200).

for GFAP, while S-100 - reaction was moderately positive with no reactivity to synaptophysin and Ki-67 index at the level of 5\% labeled nuclei of reactive lesion (Fig. 5d).

\section{DIFFERENTIAL DIAGNOSIS}

There are some malignant neoplasms of eye ball that could be considered in differential diagnosis of any eye ball tumor. ${ }^{18}$ However, differential diagnosis of retinal gliosis includes rare retinal glial neoplasms, most of which are associated with inherited syndromes like pilocytic astrocytoma in neurofibromatosis type 1 and subependymal giant cell astrocytoma in tuberous sclerosis complex, to note the most siginificant ones. ${ }^{19}$ Even rarer tumors are diffuse astrocytomas of acquired nature and conventional histopathology. ${ }^{19}$ The last one glial neoplasm in frequency is ependymoma with only few cases reported. ${ }^{19}$ However, retinal ependymoma is considered in differential diagnosis particularly due to hyalinized vessels that could occur in both of lesions but with distinctive morphology. ${ }^{19}$ In my cases, hyalinized vessels of massive retinal gliosis could have been reminiscent of hyalinized vessels of ependymoma but on closer inspection eventuality of ependymoma was excluded. Massive retinal gliosis (MRG) should be differentiated from vasoproliferative tumor of the retina and acquired retinal hemangiomas, all of which could be different phenotypically reactive lesions along a spectrum of the same disease process..$^{20}$ Actually, in sensu largo, retinal gliosis should be differentiated with virtually every intraocular tumor (retinoblastoma, uveal melanoma, ciliary body medulloepithelioma, retinal capillary hemangioma, ciliary body leiomyoma) and tumor-like lesion of different non neoplastic nature (primary hyperplastic persistent vitreous (PHPV), Coats disease, retinopathy of prematurity (ROP) with total retinal detachment etc.) particularly, if it occurs in childhood. ${ }^{16}$ 

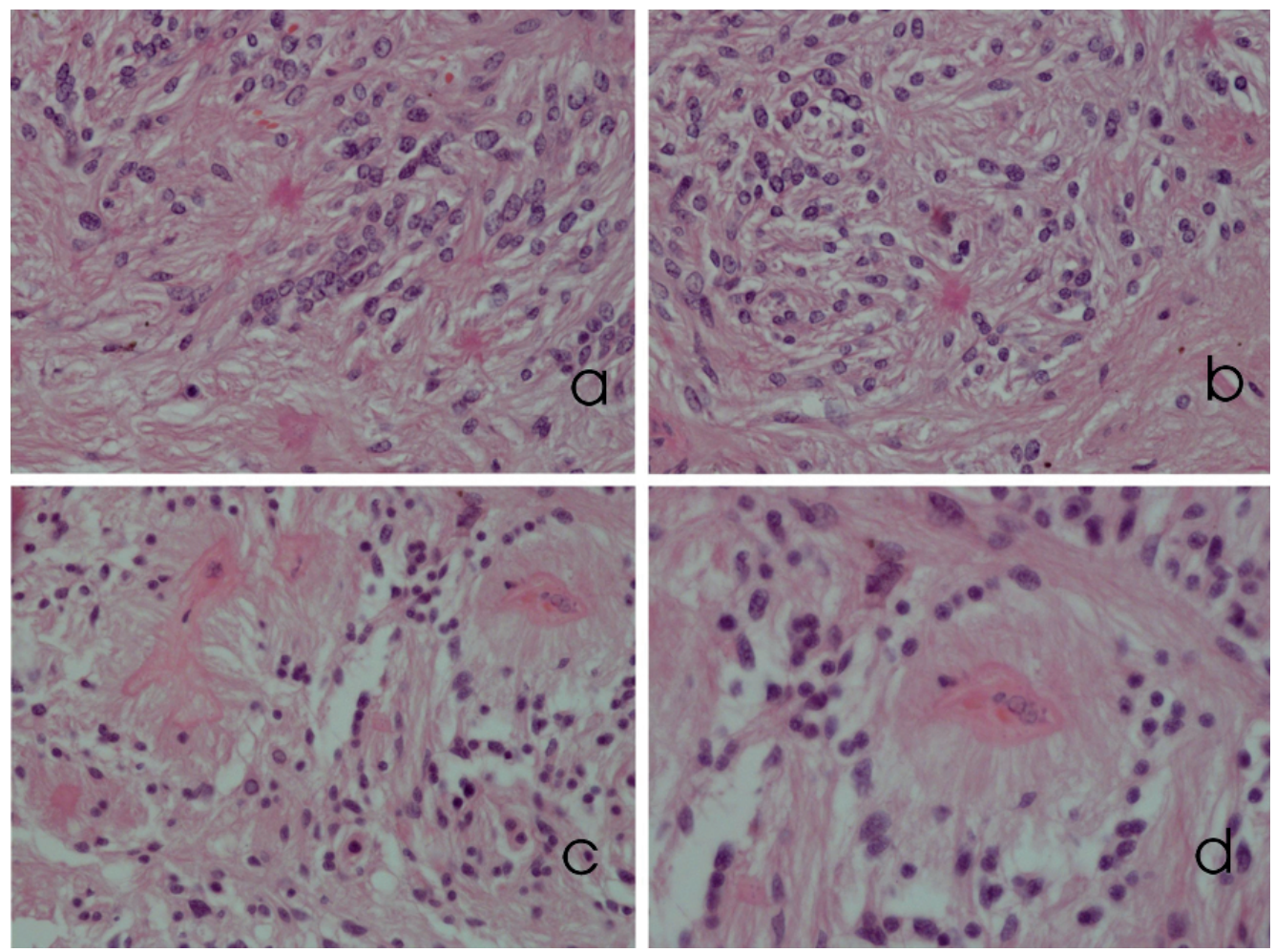

Figure 4. Degenerative changes in retinal gliosis; 4ab. Patchy hyalinised microfoci within gliosis (H\&E, Magnification 1:400); 4cd. Different aspects of hyalinized vessels within glial texture of the lesion (H\&E, Magnification 4c 1:200, Magnification 4d: 1:600).
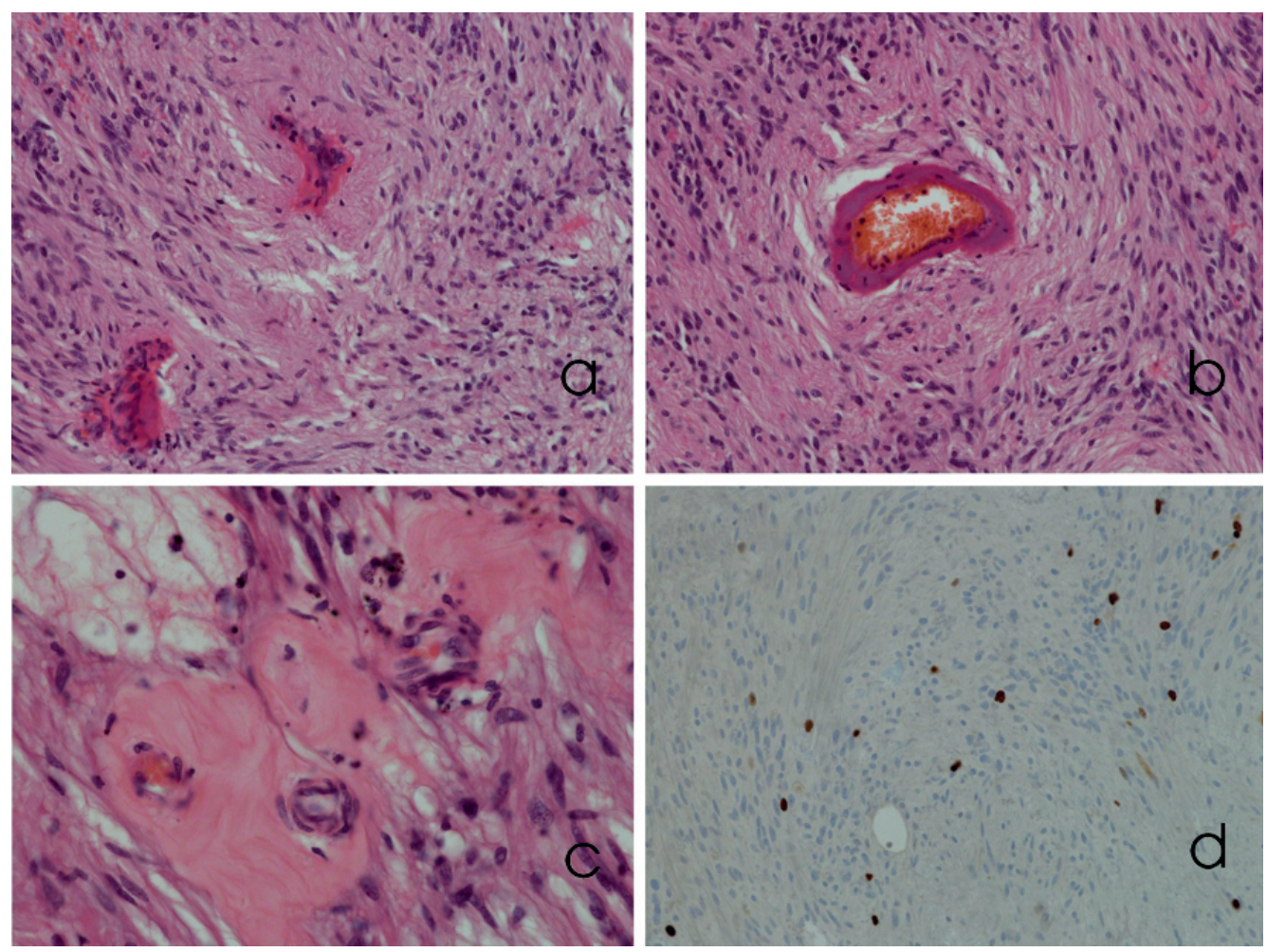

Figure 5. Degenerative changes in retinal gliosis \& MIB index; 5ab. Spindle cells of the reactive gliosis and thickly hyalinized vessels (H\&E, Magnification 1:200); 5c. Hyalinized focally acellular and hypocellular stroma adjacent to vessels of gliosis (H\&E, Magnification 1:400; 5d. Ki-67 immunolabeling of the lesion ( Anti-Ki67 staining, Magnification 1:200). 


\section{MOLECULAR BACKGROUND}

Sometimes mistaken for an intraocular tumor of neoplastic nature, MRG - considered as a type of reactive gliosis - can arise from a neurodegenerative disease, congenital defect, vascular diseases, glaucoma, or from trauma to the eyeball, sometimes appearing years after such an incident. ${ }^{2,3,20}$ Retinal gliosis could be induced by kainic acid, while retinal destruction is also mediated by astrocytic proteases that cause injury to retinal ganglion cells with detrimental impairment of vision. ${ }^{21}$ Bilateral MRG was also reported to associate with retinopathy of prematurity as well. ${ }^{20}$ Retinal reactive gliosis is responsive growth to various traumatic injuries of retina e.g. metabolic injury in course of diabetic retinopathy. ${ }^{11}$ Retinal reactive gliosis could be sustained with knockdown of retinal noncoding RNA 3 (RNCR3) and ceasing the function of RNCR3 results in reduction of viability and proliferation with diminished expression of GFAP and vimentin of Müller cells in vitro as well decrease of various cytokines that are drivers of retinal neurodegeneration in diabetes mellitus. ${ }^{10,11}$ As a proof of non neoplastic nature, MRG was shown to be polyclonal in nature in analysis of tumor clonality using a human androgen receptor assay in case of a 32-year-old woman with bilateral microphthalmia. ${ }^{22}$ The lesion classically was composed of spindle cells with delicate fibrillary cytoplasm and glial fibrillary acidic protein and neuron-specific enolase and partly S-100 protein positivity consistent with mainly non-atypical astrocytes with atrophic residues of retinal epithelium and sclera at the margins of the lesion. ${ }^{22}$ The same pattern of staining for GFAP and S100 was revealed in our present report. The lesion classically contains GFAP-positive spindled fibrous astrocytes with Alcian blue negativity of stroma as well as no aberration of TP53 gene and normal level of p16 expression. ${ }^{1}$ Retinal gliosis is associated with fibrous and osseous metaplasia of retinal epithelium, which constitute peripheral eggshell-like calcification that could be detected with clinical imaging. ${ }^{1}$ There were noted microcysts and macrocysts, vascular sclerosis, exudates, calcospherites, and Rosenthal fibers within the lesion. ${ }^{1}$ Taylor et al. provided profound and refreshing insight in pathophisology of reactive gliosis in experimental study on adult rat retinal explants of early interactions of retinal Müller glial cells after retinal trauma before gliotic remodeling and the overexpresssion of intermediate filament glial fibrillary acidic protein (GFAP), traditionally regarded as most sensitive early hallmark of reactive gliosis. ${ }^{23}$ In that study it was revealed that moderate to massive apoptosis, GFAP upregulation and gliotic remodeling were preceded by depletion of four retinal homeostatic protein regulators glutamine synthetase (GS), cellular retinaldehyde binding protein (CRALBP), basic fibroblast growth factor (bFGF) and carbonic anhydrase II (CAII) in Müller cells. ${ }^{23}$ Thus, such defined Müller cell reactivity - which constitute the so called 'pre-gliotic events'- is triggering the whole induction of glial proliferation in onset of MRG. ${ }^{23}$

\section{THERAPEUTIC OPTIONS}

Determination of sequence of MRG events is pivotal for development of novel eyeball sparing therapeutic methods. Massive retinal gliosis was reported to develop 17 years following successful non-drainage retinal detachment surgery in a 64 -year-old woman. ${ }^{24}$ Massive retinal gliosis could be removed with endoresection, which is both satisfactory in providing tissue material for histopathological evaluation as well as it is limited, eyeball-sparing method of treatment in a functioning eye. ${ }^{24}$ Among the latest approaches to therapy that utilizes vitreous substitute candidates, the study of Barth et al. seems to be noteworthy in case of reactive gliosis management. Namely, the effect of three vitreous substitute candidates were evaluated on explanted adult rat retinas. ${ }^{25}$ In opposition to polyalkylimide hydrogel and poly (ethylene glycol) a cross-linked sodium hyaluronic acid hydrogel preserved only normal lamination of retina with remarkably better condition of retinal neurons in comparison to controls with almost no apoptotic changes in retinal explants. ${ }^{25}$ Thus, a cross-linked sodium hyaluronic acid hydrogel appeared to be protective against trauma induced reactive retinal changes and to be the most promising in perspective of treatment that limit the vitreoretinal disorders, which included disruption of retinal cell layers, cell death and gliosis. ${ }^{25}$ Anyway, surgical removal of the whole eyeball remains the most straightforward method of treatment of retinal gliosis when even it affects a blind eye with phthisis bulbi as in our three presented cases.

\section{CONCLUSIONS}

In conclusion, a real 'take-away' lesson is that diagnosis of retinal gliosis should not only be made on the basis of knowledge of histological structure of retina, but it is welcomed to be classified into one of three groups of this category proposed by 
Jakobiec et al. (submassive gliosis, and massive gliosis, focal nodular gliosis), because a name of massive one is a kind of misnomer for truly focal lesions of the same nature, but with really limited extend in the intraocular space. ${ }^{1}$

\section{REFERENCES}

1. Jakobiec FA, Thanos A, Stagner AM, et al. So-called massive retinal gliosis: A critical review and reappraisal. Surv Ophthalmol 2016;61(3):339-56.

2. Hiscott $\mathrm{P}$, Mudhar H. Is vasoproliferative tumour (reactive retinal glioangiosis) part of the spectrum of proliferative vitreoretinopathy? Eye (Lond) 2009;23(9):1851-8.

3. Ulbricht E, Pannicke T, Uhlmann S, et al. Activation of retinal microglial cells is not associated with Müller cell reactivity in vitrectomized rabbit eyes. Acta Ophthalmol 2013;91(1):e48-55.

4. Nork TM, Ghobrial MW, Peyman GA, et al. Massive retinal gliosis. A reactive proliferation of Müller cells. Arch Ophthalmol 1986;104(9):1383-9.

5. Fryczkowski AW, Bieganowski L, Nye CN. Witelo - Polish vision scientist of the middle ages: father of physiological optics. Surv Ophthalmol 1996;41(3):255-60.

6. Gartner L. Textbook of Histology. 4th ed. Philadelphia: Elsevier; 2016.

7. Piccolino M, Strettoi E, Laurenzi E. Santiago Ramón y Cajal, the retina and the neuron theory. Doc Ophthalmol 1989;71(2):123-41.

8. Turner DL, Cepko CL. A common progenitor for neurons and glia persists in rat retina late in development. Nature 1987;328(6126):131-6.

9. Reichenbach A, Robinson SR. The involvement of Müller cells in the outer retina. In: Djamgoz MBA, Archer SN, Vallerga S, editors. Neurobiology and clinical aspects of the outer retina. London: Chapman \& Hall; 1995. p. 395-416.

10. Winkler BS, Arnold MJ, Brassell MA, et al. Energy metabolism in human retinal Müller cells. Invest Ophthalmol Vis Sci 2000;41(10):3183-90.

11. Liu C, Li CP, Wang JJ, et al. RNCR3 knockdown inhibits diabetes mellitus-induced retinal reactive gliosis. Biochem Biophys Res Commun 2016;479(2):198-203.

12. Chan-Ling T. Glial, neuronal and vascular interac- tions in the mammalian retina. Prog Ret Eye Res 1994;13:357-89.

13. Ginhoux F, Lim S, Hoeffel G, et al. Origin and differentiation of microglia. Front Cell Neurosci 2013;7:45.

14. Schnitzer J. Retinal astrocytes: their restriction to vascularized parts of the mammalian retina. Neurosci Lett 1987;78:29-34.

15. Sorrentino FS, Allkabes M, Salsini G, et al. The importance of glial cells in the homeostasis of the retinal microenvironment and their pivotal role in the course of diabetic retinopathy. Life Sci 2016;162:54-9.

16. Potter PD, Shields CL, Shields JA, et al. The role of magnetic resonance imaging in children with intraocular tumors and simulating lesions. Ophthalmology 1996;103:1774-83.

17. Taha H, Amer HZ, El-Zomor H, et al. Phthisis bulbi: clinical and pathologic findings in retinoblastoma. Fetal Pediatr Pathol 2015;34:176-84.

18. Chilova-Atanasova B, Sivkova N. Malignant tumors of the eyeball and its accessories. Folia Med (Plovdiv) 1995;37(4A Suppl):89.

19. Tay A, Scheithauer BW, Cameron JD, et al. Retinal ependymoma: an immunohistologic and ultrastructural study. Hum Pathol 2009;40:578-83.

20. Houston SK, Bourne TD, Lopes MB, et al. Bilateral massive retinal gliosis associated with retinopathy of prematurity. Arch Pathol Lab Med 2009; 133:1242-5.

21. Ganesh BS, Chintala SK. Inhibition of reactive gliosis attenuates excitotoxicity-mediated death of retinal ganglion cells. PLoS One 2011;6:e18305.

22. Inayama $Y$, Hanashi M, Yazawa T, et al. Massive gliosis of the retina: report of a case investigated by immunohistochemistry and clonality assays. Hum Pathol 2005;36:702-5.

23. Taylor L, Arnér K, Ghosh F. First responders: dynamics of pre-gliotic Müller cell responses in the isolated adult rat retina. Curr Eye Res 2015;40:1245-60.

24. Gelisken F, Inhoffen W, Rohrbach JM, et al. Massive retinal gliosis: a late complication of retinal detachment surgery. Graefes Arch Clin Exp Ophthalmol 2004; 242:255-8.

25. Barth H, Crafoord S, O'Shea TM, et al. A new model for in vitro testing of vitreous substitute candidates. Graefes Arch Clin Exp Ophthalmol 2014;252:1581-92. 


\title{
Обзор литературы в области глиоза сетчатки, на основе серии случаев массивных глиозов и очаговых нодулярных глиозов, в связи с потенциальными ошибками при реактивных опухолепо- добных поражениях глаз данного типа
}

\author{
Анджей Винцевич ${ }^{1}$, Славка Урбаниак-Вашик ${ }^{1}$, Антоанет Урбаниак ${ }^{1}$, Марлена Мошчицка- \\ Рилска², Мартина Волтановска ${ }^{3}$, Мариуш Кода ${ }^{3}$, Станислав Сулковски ${ }^{3}$, Йоанна Решеч ${ }^{4}$ \\ 1 Частный медицинский центр - Кафедра патологии, Кельце, Польша \\ 2 Частный медицинский центр - первичное здравоохранение (NZOZ POZ) MEDICAMENTO, Wysokie Mazowieckie, Польша, \\ Польша \\ ${ }^{3}$ Кафедра общей патоморфологии, Медицинский университет Белосток, Белосток, Польша \\ ${ }^{4}$ Кафедра медицинской патоморфологии, Медицинский университет Белосток, Белосток, Польша
}

\begin{abstract}
Адрес для корреспонденции: Анджей Винцевич, Кафедра патологии, Центр специализированной медицинской практики, Ягелонска 70, Кельце, 25-734 Польша

Email:andwinc@gmail.com Тел: +48506660426
\end{abstract}

Дата получения: 01 марта 2017 Дата приемки: 30 мая 2017 Дата онлайн публикации: 23 июня 2017

Дата публикации: 30 марта 2018

Ключевые слова: глиоз сетчатки, внутриглазная опухоль, реактивные изменения, фибриллярные астроциты, клетки Мюллера

\section{Образец цитирования:}

Wincewicz A, Urbaniak-Wasik S, Urbaniak A, Mościcka-Rylska M, Woltanowska M, Koda M, Sulkowski S, Reszeć J. Review on retinal gliosis illustrated with a series of massive glioses and focal nodular gliosis cases in regard to potential pitfalls of ocular reactive tumorlike lesions of this type. Folia Med (Plovdiv) 2018;60(1):30-8.

doi: 10.1515/folmed-2017-0061
Данная статья представляет собой обзор литературы в области глиоза сетчатки, охватывающий серию из трёх случаев заболевания ( 39-летний мужчина и 35-летняя женщина с массивным глиозом сетчатки (МГС) и 51-летний мужчина с действительным очаговым нодулярным глиозом сетчатки) с внутреглазными опухолеподобными структурами и потерей зрения, которые в последнее время получили болезненное воспаление глазного яблока и у которых наличествует анамнез предшествующей глазной травмы, начало ранней слепоты или постепенной, но прогрессирующей потери зрения. Диагноз данного патологического состояния ставится на основании наличия очагов поражений, составленных из GFAP (глиальный фибриллярный кислый белок) положительных, удлиннённых веретенообразных клеток, соответствующих фибриллярным астроцитам. Как установлено в случаях нашей патологической практики, PAS-реакция выявляет положительную неоднородную диссеминированную реакцию в виде клеточных густых гранул лиловатой окраски в меньшем количестве клеток, указывающих на сохранение гликогена. Данная характеристика может быть совместимой с PAS-положительными клетками Мюллера, которые тоже наличествуют при глиозе сетчатки в качестве клеточного компонента нормальной сетчатки, вызывающей реактивную пролиферацию. Таким образом настоящая статья представляет собой гистологическую основу и дифференциальный диагноз данной единицы. 